\title{
Growing pains for Amgen as epoetin wins US approval
}

\section{- Congress worries over costs - Patents disputes continue}

\section{Washington}

Two weeks ago, Amgen Corporation finally capped eight years of research with permission from the Food and Drug Administration to sell epoetin, a genetically-engineered copy of erythropoietin (EPO) likely to revolutionize treatment of people with kidney failure.

But Amgen still needs stamina to complete the transition from biotechnology company to pharmaceutical supplier: it now faces questions from Congress over its prices on top of continuing patent battles and disputes with its business partner.

Epoetin, which Amgen is selling under the trade name Epogen, is a copy of EPO, a protein produced by the kidneys that triggers the production of red blood cells in bone marrow. Lacking EPO, patients with kidney failure commonly suffer from anaemia. But clinical trials show that treating them with epoetin restores redblood-cell production, making regular blood transfusions unnecessary.

On 1 June, the Food and Drug Administration (FDA) specifically approved the drug for treatment of anaemia in kidney failure, opening use of the drug to some 95,000 people in the United States. But the market for epoetin is likely to go beyond kidney patients to others needing to increase red-blood-cell production. That could include AIDS and cancer patients and people recovering from operations. According to Shearson Lehman Hutton, a stock analysis company, the US market for epoetin could exceed two thousand million dollars by 1993 , making it one of the world's best-selling drugs.

Alongside FDA approval, Epogen was given "orphan drug" status under an act that provides special incentives for treatments for diseases or conditions affecting fewer than 200,000 US patients. The incentives include a seven-year period when competitive manufacture of an identical product is prohibited.

These successes for Amgen have helped make Congress worry that the government will have to pay too much for Epogen through the Medicare scheme that covers kidney-dialysis patients.

Congressman Fortney Stark (Democrat, California), chairman of the House of Representatives Ways and Means health subcommittee is concerned that the price of Epogen, at between $\$ 4,000$ and $\$ 8,000$ for a year's treatment, would grant Amgen a huge return on its investment. But Amgen points to the legal difficulties that still surround it and the gigantic gamble it took in investing several hundred million dollars in the research and development of a single product.

On the legal front, Amgen is in triple trouble, embroiled in disputes with its competitors Genetics Institute and Chugai Pharmaceuticals, and a separate dispute over its market share with marketing partner, Johnson \& Johnson.

Amgen and Genetics Institute both hold EPO patents. Amgen's patent includes the EPO gene and the geneticallyengineered cells that make EPO, but not the final product. Genetics Institute holds a patent for "homogenous [HUMAN] EPO" and takes that to mean all human EPO, even though the company obtained its EPO by purifying it from urine.

As genetically-engincered cells are essential to make large quantities of EPO, the situation is perfect for dispute: Genetics Institute has a claim on the final destination and Amgen on the only way of getting there.

In the meantime, Genetics Institute's licensee, Chugai Pharmaceuticals, has succeeded in importing genetically-engineered EPO made in Japan. Amgen tried to block the imports with an appeal to the International Trade Commission. But, although the judge was sympathetic, nothing could be done to prevent offshore production of recombinant EPO.

Amgen's third quarrel, with Johnson \& Johnson's Ortho, seems just as difficult, even though it is a battle with a partner. Their disagreement is over what their agreement means. Amgen granted Johnson \& Johnson's Ortho the right to the non-kidney dialysis market for cash and advice. But the companies cannot now agree over the boundaries of their market shares and are engaged in arbitration.

All of Amgen's legal troubles are unlikely to destroy the company. At worst, Amgen may be forced into cross-licensing agreements with other companies. But Congressional interest in the prices of the new products of genetic engineering raises new questions. The US government's decision that Genentech's tissue plasminogen activator was too expensive for the Medicare scheme (see Nature 332, 577; 14 April 1988) hit hard at Genentech's plans to become a major pharmaceutical producer. But as a major purchaser of drugs, a spokesman for representative Stark says Congress has "no choice" but to question prices.

Alun Anderson
Expressions of outrage

Washington \& Tokyo

THE US National Academy of Sciences suspended its cooperative exchange programme with the Chinese Academy of Sciences and other Chinese institutions last week in response to the killing of demonstrators in Tiananmen Square by Chinese troops. A telegram from Frank Press, President of the National Academy of Sciences to Professor Zhou Guangzhao, president of the Chinese Academy of Sciences expressed "outrage and sadness" and said, "We are shocked and dismayed by the action of Chinese government troops against peaceful demonstrators."

In the United States and Japan, the two most popular destinations for Chinese students, governments moved to reassure Chinese students that they would not be compelled to return home while the present troubles continue. The United

\section{IMAGE UNAVAILABLE FOR COPYRIGHT REASONS}

\section{Fang Lizhi in better times.}

States has approximately 40,000 students from China, Japan has almost 8,000.

China's best-known dissident, astrophysicist Fang Lizhi, and his wife $\mathrm{Li}$ Shuxian, were still in the US Embassy in Beijing on June 12 after seeking sanctuary there a week earlier. The Chinese government has issued arrest warrants for both Fang and $\mathrm{Li}$ as part of their crack down on protestors. The US government has said that it does not hand over dissidents in danger of being killed, a stand that is likely to precipitate a diplomatic crisis with the Chinese government. According to the Washington Post, Fang has also been criticised by Chinese intellectuals for his "melodramatic" decision to seek US protection because it could be used to support government propaganda that the democracy movement was foreigninspired.

Alun Anderson \& David Swinbanks 